\title{
Peran Proses Mentoring Pemimpin Kaum Muda Bagi Perkembangan Pelayanan Pemuda Di Gereja
}

\section{The Role of the Process of Mentoring Youth Leaders for the Development of Youth Services in the Church}

\author{
Agus Prihantol)* \\ 1) Pendidikan Agama Kristen, Sekolah Tinggi Teologi Blessing Indonesia Makassar \\ *)Penulis korespondensi: agusprihanto1971@gmail.com
}

Received: 30 September 2017/Revised: 08 May 2018 /Accepted: 09 June 2018

\begin{abstract}
Abstrak
Masalah saat ini yang banyak dialami oleh gereja-gereja adalah kurangnya pemimpin-pemimpin yang memiliki kemampuan yang cukup untuk mengembangkan pelayanan di gereja. Gereja yang seharusnya menghasilkan pemimpin yang memiliki iman yang benar, ilmu yang memadai, dan pengabdian yang sungguh-sungguh, malah mengalami krisis kepemimpinan. Absennya kepemimpinan yang efektif akan mengakibatkan gereja kekurangan pemimpin berkualitas di masa yang akan datang. Untuk itu gereja harus memulai memikirkan bagaimana menghasilkan pemimpin-pemimpin gereja untuk masa yang akan datang. Gereja harus memulai dengan mempersiapkan pemimpinpemimpin muda yang dapat diandalkan, mulai dari sekarang. Cara yang terbaik dan sesuai dengan firman Tuhan untuk dapat menghasilkan pemimpin adalah dengan cara pemuridan atau yang sekarang sering disebut dengan mentoring. Namun sayangnya masih banyak pemimpin-pemimpin, khususnya pemimpin kaum muda yang kurang memahami tentang mentoring. Mentoring merupakan proses pembentukan pemimpin agar nantinya pemimpin-pemimpin yang dihasilkan merupakan pemimpin yang berkualitas. Pemimpin kaum muda harus memahami bahwa mentoring harus dikerjakan dengan cara memberi teladan kepada setiap anggotanya. Kemudian pemimpin kaum muda harus melatih dan membimbing anggotanya agar dapat memahami tentang kepemimpinan. Tahap selanjutnya adalah mengutus mereka sebagai pemimpin yang baru agar mereka dapat bermultiplikasi. Dampak dari perkembangan pelayanan ini akan menghasilkan jiwa-jiwa dan semuanya itu untuk kemuliaan Tuhan.
\end{abstract}

Kata-kata kunci: Pemimpin kaum muda, mentoring, perkembangan pelayanan

The current problem that many churches face today is the lack of leaders who have sufficient ability to develop ministry in the church. The church that should produce leaders who have true faith, adequate knowledge and genuine devotion, even experience a leadership crisis. The absence of effective leadership will result in the Church's lack of even future leader runs out. For that, the Church must begin to think about how to produce church leaders for the future. The church must begin by preparing reliable young leaders, from now on. The best way and according to the Word of God to be able to produce leaders is by discipleship or 
what is now called mentoring. But unfortunately, there are still many leaders, especially young leaders who lack understanding about mentoring. Mentoring is the process of forming leaders so that leaders will be produced the qualified leader. Young leaders must understand that mentoring must be done by example of each member. Then the youth leader must train and guide its members to understand leadership. The next stage is to send them as new leaders so they can multiply. A church with good youth leadership will have an impact on the development of youth ministry in the church. The impact of the development of this ministry will produce souls and all of them for the glory of God.

Keywords: Youth leaders, mentoring, service development

\section{Pendahuluan}

Pemimpin yang tidak visioner, tidak berintegritas tinggi, tidak cerdas dapat mencelakakan mereka yang dipimpinnya, bahkan juga kalangan lain. ' Baik buruknya kualitas seorang pemimpin akan memengaruhi keberhasilan proses kepemimpinan yang dikerjakannya.

Dalam buku Josua Iwan Wahyudi berjudul Pharaoh Leadership menjelaskan hasil survei tentang kualitas leader yang dikagumi adalah: ${ }^{2}$

1. Mampu memberi visi yang memaksimalkan seluruh individu;

2. Mampu untuk memotivasi dan menginspirasi untuk bertindak;

3. Mendengar bawahan;

4. Mengenal bawahan secara personal masing-masing individu;

5. Membela tim.

Berdasarkan survei di atas kita melihat bahwa kenyataan bahwa seorang pemimpin yang berkualitas bukanlah pemimpin yang memiliki kemampuan teknis yang luar biasa, tetapi yang dituntut dari seorang pemimpin yang berkualitas adalah apakah seorang pemimpin dapat menjadi dampak bagi bawahannya.

Gereja pun saat ini tidaklah kebal terhadap krisis kepemimpinan. Gereja yang seharusnya menghasilkan pemimpin yang memiliki iman yang benar, ilmu yang memadai, dan pengabdian yang sunguh-sungguh, malah terkontaminasi dengan berbagai masalah kepemimpinan. Peneliti George Barna menyimpulkan hasil studinya selama 15 tahun tentang kehidupan dalam gereja secara global dengan konklusi sebagai berikut: Gereja telah kehilangan pengaruh karena absennya kepemimpinan yang efektif. ${ }^{3}$

${ }^{1}$ Robby Chandra, Landasan Pacu Kepemimpinan (Yogyakarta: Gloria Graffa, 2004), 2013), 24

2 Josua Iwan Wahyudi, Pharaoh Leadership (Jakarta: Get Yor Wisdom Publishing,

${ }^{3}$ Sendjaya, Konsep Karakter Kompetensi Kepemimpinan Kristen (Yogyakarta: Kairos Books, 2004), 17. 
Absennya kepemimpinan yang efektif akan mengakibatkan gereja kekurangan pemimpin di masa yang akan datang, dan hal ini sangatlah berbahaya bagi gereja Tuhan di masa yang akan datang. Untuk itu gereja harus mulai memikirkan bagaimana menghasilkan pemimpin-pemimpin gereja untuk masa yang akan datang. Tugas ini merupakan bagian yang harus dikerjakan oleh gereja masa kini.

Seorang pemimpin bukan hanya mampu untuk mengatur anggotanya untuk mencapai tujuan bersama saja, tetapi mereka juga harus mampu melatih dan menuntun anggotanya agar dapat mengerjakan tugas seperti yang pemimpin dapat lakukan. Seorang pemimpin harus dapat menghasilkan pemimpin-pemimpin yang baru. Sehubungan dengan hal itu maka perlu adanya yang namanya mentoring. Apakah yang dimaksud dengan mentoring?

\section{Mentoring}

Kata mentoring berasal dari kata mentor dan kata ini sudah menjadi kata yang baku dalam Bahasa Indonesia. Arti kata mentor adalah pembimbing atau pengasuh. ${ }^{4}$ Kata mentor diterjemahkan menjadi kata "penasihat". ${ }^{5}$ Sedangkan dalam Webster's New Collegiate Dictionary pengertian mentor diartikan dengan menutupi, penasihat yang dipercaya, atau pelatih. ${ }^{6}$

Mentoring didefinisikan untuk mengembangkan kapasitas potensial dan kompetensi individu dalam pelayanan sebagai pembelajaran yang akomodatif bagi hubungan antara individu yang peduli yang berbagi pengetahuan, nilai, sikap, pengalaman, dan kebijaksanaan dengan individu lain. ${ }^{7}$

Caffarella mendefinisikan mentoring sebagai berikut: "Mentoring is intensif, caring relationship in which someone with experience works with aless experienced person to promote both professional growths." Mentoring merupakan suatu hubungan yang intens di mana seorang yang memiliki pengalaman bekerja dengan orang yang kurang berpengalaman untuk menolong atau mempromosikan orang yang kurang berpengalaman baik dalam

\footnotetext{
4 “Mentor," diakses 28 Agustus 2017, https://kbbi.web.id/mentor

${ }^{5}$ John M. Echols, Hasan Shadily, Kamus Inggris - Indonesia (Jakarta: Gramedia, 1981), 378, s.v. "Mentor".

${ }^{6}$ Merriam -Webster, Webster's New Collegiate Dictionary (G \& C. Merriam Co., 1973), 718, s.v. "Mentor".

${ }^{7}$ N. H. Chiroma, A. Cloete, "Mentoring as a supportive pedagogy in theological training," HTS Teologiese Studies/ Theological Studies 71, no. 3 (2015): 2, http:// dx.doi.org/10.4102/hts. v7li3.2695

${ }^{8}$ Rosemary S. Cafferella, Planning Programs for Adult Learners: A Practical Guide for Educators, Trainers and Staff Developers (San Fransisco: Jossey-Bass Publishers, 1994).
} 
profesional ataupun dalam pertumbuhan pribadi. Dengan kata lain, mentoring adalah proses seseorang membantu orang lain untuk belajar sesuatu, membuka hidupnya kepada orang lain, membagikan kehidupan dengan orang lain, sehingga menjadi sebuah proses di mana seseorang hidup untuk menghasilkan generasi yang akan datang.

Masalah gereja masa kini mengalami kegagalan dalam meregenerasi pemimpin, sehingga kurangnya pemimpin-pemimpin baru yang lahir. Kalaupun ada, pemimpin baru tersebut memiliki kecenderungan memiliki kualitas kepemimpinan yang tidak memadai. Pemimpin yang baru tidak mengerti apa yang harus mereka lakukan, karena sebelumnya mereka tidak pernah diajarkan dan kalaupun pemimpin yang baru tersebut mengetahuinya. Masalahnya adalah bagaimana mereka harus melakukan, karena tidak memiliki keterampilan dan keberanian untuk melakukannya. Hal ini dikarenakan kurangnya pelatihan dan dukungan ataupun kepercayaan yang diberikan oleh pemimpin sebelumnya kepada mereka. Dengan kata lain, minimnya proses mentoring bagi pemimpin baru dilakukan dalam gereja terutama untuk kaum muda.

Kenyataannya saat ini gereja banyak kehilangan kaum muda dan khususnya kehilangan pemimpin kaum muda. Mengapa hal ini terjadi? Salah satu alasannya mengapa anak muda meninggalkan gereja adalah anak muda seharusnya dibimbing, dan didukung dalam perkembangannya, bukan hanya diberikan pengajaran. Pemimpin kaum muda harus dapat memahami dan melaksanakan proses mentoring agar anak muda tidak meninggalkan gereja. Jika hal itu dibiarkan terjadi maka akan makin banyak anak muda meninggalkan gereja. Hal ini dapat mengakibatkan tidak adanya perkembangan dalam pelayanan pemuda di gereja, bahkan dapat mengakibatkan kemunduran dalam pelayanan kaum muda.

Salah satu contoh perkembangan statistik pelayanan generasi muda di Korea Selatan belum lama ini, menunjukkan kekristenan di negara tersebut mengalami penurunan. Lebih menyedihkan lagi, anak-anak muda usia berkisar 15-20 tahun telah meninggalkan gereja dan hanya sekitar 2,9 persen dari mereka yang mau mengakui diri sebagai pengikut Kristus. ${ }^{9}$ The Barna Group, sebuah perusahaan riset, telah menemukan bahwa hampir 60 persen anak muda usia 15-29 tahun telah meninggalkan keterlibatannya secara aktif di gereja. Fenomena ini telah dikaji ulang oleh peneliti David Kinnaman dalam buku barunya, You Lost Me: Why Young Christians are Leaving Church and Rethinking Faith (Anda Telah Kehilangan

9 "COO CBN Indonesia: Kita Sedang Kehilangan Satu Generasi," diakses 20 Mei 2018, https:/www.jawaban.com/read/article/id/2015/06/09/90/150609170913/COOCBN-Indonesia\%3A-Kita-Sedang-Kehilangan-Satu-Generasi 
Saya: Mengapa Orang Muda Kristen Meninggalkan Gereja Dan Berpikir Ulang Soal Imannya). ${ }^{10}$

Menurut survei yang diadakan oleh Bilangan Research Center pada 4.095 anak remaja di Indonesia di tahun 2017, rata-rata anak muda yang mengikuti ibadah 4 kali dalam 3 bulan sebesar $63.8 \%$ sedangkan sisanya hanya 2 atau 3 kali ibadah. ${ }^{11} \mathrm{Hal}$ ini menunjukkan bahwa pada saat ini anak muda di Indonesia sudah jarang ke gereja, kalaupun ke gereja paling hanya hari Minggu saja. Penelitian itu membuktikan bahwa generasi muda saat ini mulai meninggalkan gereja. Hal ini tidak boleh terus dibiarkan, karena jika terus-menerus dibiarkan, maka gereja lamakelamaan akan menjadi kosong.

Untuk mengevaluasi dan memilih program pembinaan rohani untuk generasi milenium, maka penting untuk mempertimbangkan data dan tren yang tersedia saat ini berkenaan dengan spiritualitas mereka. Banyak hal yang menunjukkan perbedaan penting antara generasi yang millennial, dan generasi sebelumnya. Generasi Millenial mempertanyakan keyakinan masa lalu, dan sebagian besar (72\%) tidak lagi mengikat identitas mereka dengan keyakinan agama seperti yang dilakukan orang tua mereka. ${ }^{12}$

Peran mentoring pemimpin kaum muda dapat memengaruhi bagi perkembangan pelayanan pemuda di gereja. Tetapi permasalahannya adalah: Pertama, apakah yang dimaksud dengan pemahaman pemimpin kaum muda tentang mentoring, dan peran pemimpin dalam proses mentoring kaum muda bagi perkembangan pelayanan pemuda? Kedua, apa dampaknya bagi perkembangan pelayanan pemuda di gereja?

\section{Peran Pemimpin dalam Proses Mentoring}

Mentoring sangat berkaitan erat dengan masalah kepemimpinan (leadership) di mana seseorang (mentor) memiliki inisiatif dalam

10 "Fakta Yang Menyebabkan Anak Muda Meninggalkan Gereja. Apakah Gereja Mau Berdiam Diri Saja?" diakses 5 Mei 2018,

http://www.superbookindonesia.com/article/read/584; David Kinnaman, You Lost Me: Why Young Christians Are Leaving Church ... and Rethinking Faith (Grand Rapid, MI: Baker Books, 2011).

11 "Fakta Yang Menyebabkan Anak Muda Meninggalkan Gereja. Apakah Gereja Mau Berdiam Diri Saja?" diakses 5 Mei 2018, http://www.superbookindonesia.com/article/read/584

${ }^{12}$ Anne Puidk Horan, "Fostering Spiritual Formation of Millennials in Christian Schools," Journal of Research on Christian Education 26, no. 1 (2017): 59, http://dx.doi.org/10.1080/10656219.2017.1282901; Barna Group, "Year in review: Barna's top 10 findings in 2015. Culture \& Media," retrieved from https://barna.org/research/culture-media/article/year-in-review-2015; Dean, 2010; Winograd \& Hais, 2011. 
membimbing serta memimpin orang lain (mentee) sehingga orang lain yang dibimbing dan dipimpinnya di kemudian hari dapat menjadi maksimal dalam segala aspek kehidupannya. ${ }^{13}$ Mentoring merupakan sebuah istilah yang banyak digunakan di dalam dunia usaha maupun di lingkungan gereja yang dihubungkan dengan kepemimpinan. Peran mentoring telah menjadi sebuah kebutuhan yang sangat vital bagi pertumbuhan di berbagai bidang, baik di dalam gereja, maupun dalam dunia usaha atau dalam organisasi kemasyarakatan.

Proses pemuridan (mentoring) merupakan perintah dari Tuhan Yesus yang wajib kita kerjakan. Dan perintah ini bukan hanya sekadar diucapkan oleh Tuhan Yesus, tetapi Ia juga memberikan teladan untuk melakukan proses pemuridan (mentoring) tersebut. Seorang pemimpin harus memahami tentang mentoring, bahkan menerapkan proses mentoring dalam kepemimpinan-nya, kepemimpinan selanjutnya dapat berjalan dengan baik.

Pemimpin harus mempersiapkan regenerasi kepemimpinan yang baik, bahkan mungkin lebih baik dari pada dirinya sendiri. Seorang pemimpin akan menjadi serupa dengan orang yang pernah mementornya. Hal ini berarti kehidupan seorang pemimpin akan memengaruhi pemimpin baru yang dihasilkannya. Tentunya sasaran atau tujuan dari mentoring tentunya tidak lepas dari definisi mentoring tersebut. Amos Hosea, dalam artikelnya di Majalah Generasi dengan judul "Peranan Mentor dalam Pemberdayaan Pelayan," menyebutkan bahwa mentoring merupakan sebuah pengalaman yang berhubungan, di mana seseorang memberdayakan orang lain dengan sumbur-sumber yang Allah berikan. ${ }^{14}$ Mentoring bukan untuk mengumpulkan pengikut, tetapi berfungsi untuk melahirkan mentor (pemimpin) baru. Mentoring bukan untuk membuat generasi pengikut yang selalu berada di bawah kendali orang yang mementornya. Namun mentoring berfungsi untuk melahirkan para mentor baru, bahkan mungkin dapat lebih baik dari mentornya.

Suatu studi grounded theory mengeksplorasi persepsi 33 alumni dari 10 sekolah teologi evangelis Indonesia mengenai dampak mentoring informal, yang mereka alami selama waktu mereka sebagai mahasiswa. Data dari wawancara tatap muka mengungkapkan bahwa hubungan mentoring informal berdampak: a) membantu mereka untuk menangani kebutuhan sosial dan emosional mereka terutama di semester pertama dan kedua; b) memfasilitasi pertumbuhan spiritual mereka; c) membantu mereka mencapai prestasi akademik mereka. tujuan; dan d) membantu

${ }^{13}$ Togi Simanjuntak, The Art of Mentoring (Jakarta: Metanoia, 2012), 57.

${ }^{14}$ Amos Hosea, "Peranan Mentor dalam Pemberdayaan Pelayan," Majalah Generasi DPA GBI Edisi September-Desember 2007, 8. 
mereka menjadi sadar akan potensi mereka, dan mengidentifikasi panggilan, dan panggilan pelayanan mereka. ${ }^{15}$

Hasil penelitian di atas menunjukkan dampak mentoring terhadap alumni yang akhirnya menjadi pemimpin saat ini yang memahami pentingnya mentoring di masa lalu ketika mereka masih menjadi sebagai mahasiswa. Mentoring dapat terjadi dengan baik apabila pemimpin yang mementor anak muda tersebut memberikan teladan, pemahaman, pelatihan, dan bimbingan bahkan mengevaluasi setiap tugas-tugas yang dipercayakan kepada anak muda (mentee). Pemimpin anak muda dapat dikatakan memahami mentoring apabila pemimpin tersebut tidak hanya memiliki pengetahuan, dan kemampuan untuk memimpin, tetapi menjalankan proses mentoring tersebut. Paul Stanley dan Robert Clinton berpendapat, "Mentoring adalah sebuah pengalaman rasional, yang melaluinya satu orang memberdayakan orang lain dengan cara berbagi sumber-sumber yang diberikan oleh Allah." ${ }^{16}$ Tujuan dari mentoring formal adalah untuk membantu murid memahami kekuatan dan kelemahan mereka dan meningkatkannya melalui komunikasi terbuka dengan seorang mentor. ${ }^{17}$

Pemimpin anak muda yang memahami tentang mentoring maka ia akan menjalankan proses mentoring tersebut dengan cara:

\section{Menjadi Teladan}

Dalam Injil Yohanes 13:15 Tuhan Yesus mengatakan kepada muridmurid-Nya: "sebab Aku telah memberikan suatu teladan kepada kamu, supaya kamu juga berbuat sama seperti yang telah Kuperbuat kepadamu." Seorang Pemimpin anak muda yang memahami tentang mentoring tentunya ia dapat menjadi teladan bagi orang lain. Pemimpin anak muda yang paham tentang mentoring tentunya tidak akan memimpin dengan cara hanya memberi perintah saja melainkan dengan teladan.

Pemuda membutuhkan sosok atau figur yang bisa diteladani karena kebanyakan mereka tidak menemukan keteladanan tersebut di rumah mereka. Mereka tidak menemukan keteladanan tersebut dari orang tua dan juga tidak menemukan orang lain yang patut diteladani dalam pergaulan mereka maka sebenarnya mereka terus mencari orang yang dapat menjadi contoh bagi kehidupan mereka. Hal ini sebagai kebutuhan

${ }^{15}$ Leonard Sumule, "The Impact of Informal Mentoring: Perceptions of Alumni of Evangelical Theological Schools in Indonesia," Proquest LLC (2016). Penulis mengutip abstrak disertasi.

${ }^{16}$ Tim Elmore, Mentoring (Jakarta: Metanoia, 2003), 2. Tim Elmore mengutip pernyataan pakar kepemimpinan Paul Stanley dan Robert Clinton.

${ }^{17}$ Min-Kyu Joo, Gyu-Chang Yu, Leanne Atwater, "Formal leadership mentoring and motivation to lead in South Korea," Journal of Vocational Behavior 107 (August 2018): 310-326. 
mereka untuk mendapatkan orang lain yang dapat menjadi contoh bagi mereka untuk dapat dijadikan pembimbing atau panutan sekaligus mungkin menjadi seorang sahabat yang dapat mengerti dan mau menerima segala keterbatasan dan kelemahan mereka. ${ }^{18}$

Dalam Alkitab kita dapat melihat bagaimana Yesus memberi contoh kepada murid-murid-Nya dan diikuti oleh murid-murid-Nya. Yesus menyembuhkan orang lumpuh Petrus juga menyembuhkan orang lumpuh, Yesus menyembuhkan banyak orang sakit, Petrus juga melakukan hal yang sama. Yesus bayar harga dalam melayani bahkan sampai mati di kayu salib, Petrus juga melakukan hal yang sama ia mati di salib. Sebuah prinsip yang paling penting dalam melakukan mentoring adalah "kita tidak dapat melatih apa yang belum kita lakukan". Paulus tidak meminta jemaat Filipi untuk mencontoh perkataan-perkataannya saja, tetapi yang terutama adalah mencontoh teladannya. Hal ini ditulis dalam surat Filipi 3:17, "Saudara-saudara, ikutilah teladanku dan perhatikanlah mereka, yang hidup sama seperti kami yang menjadi teladanmu."

Dalam Kisah Para Rasul 1:1, Lukas mencatat apa yang Yesus kerjakan dan ajarkan. Inilah prinsip mentoring yang sangat penting. Kristus mengerjakan (menunjukkan) dulu apa yang akan diajarkan-Nya, barulah kemudian Ia mengajarkannya. Mengapa prinsip ini sangat penting dalam Kerajaan Allah? Sebab dengan melihat teladan dari apa yang kita ajarkan, orang dapat melakukannya dengan mudah. Apa saja yang kita ingin orang lain lakukan akan lebih mudah ditularkan lewat contoh langsung. Mengapa pelayanan gereja masa kini banyak yang tidak berdampak besar atas dunia? Persoalan utamanya adalah gereja tidak berfokus pada keteladanan yang menghasilkan teladan-teladan pada angkatan berikutnya. ${ }^{19}$ Tujuan hidup sebagai pemimpin anak muda adalah meneladani Kristus dan pemimpin anak muda tersebut juga harus terus-menerus menjadi teladan dan mendorong orang yang dipimpinnya untuk menjadi teladan bagi orang lain.

Seorang pemimpin anak muda harus dapat menjadi teladan bagi orang lain, khususnya orang-orang yang dimentornya, sekalipun ia masih muda. Hal ini juga yang disampaikan oleh Paulus kepada Timotius di dalam 1 Timotius 4:12 dikatakan, "Jangan seorangpun menganggap engkau rendah karena engkau muda. Jadilah teladan bagi orang-orang percaya, dalam perkataanmu, dalam tingkah lakumu, dalam kasihmu, dalam kesetiaanmu dan dalam kesucianmu." Seorang pemimpin kaum muda dapat dikatakan paham tentang mentoring jika ia dapat menjadi teladan bagi anggota yang dipimpinnya.

\footnotetext{
${ }^{18}$ Simanjuntak, 251.

${ }^{19}$ Eddy Leo, Mentoring Panduan Untuk Menuntun Hidup Orang Lain Menjadi Maksimal Dalam 49 Hari (Jakarta: Metanoia, 2007), 16.
} 


\section{Membimbing}

Dalam Kisah Para Rasul 8:30-31 saat Filipus bertemu dengan sidasida Etiopia yang sedang membaca kitab nabi Yesaya: Filipus segera ke situ dan mendengar sida-sida itu sedang membaca kitab nabi Yesaya. Kata Filipus: "Mengertikah tuan apa yang tuan baca itu? Jawabnya: 'Bagaimanakah aku dapat mengerti, kalau tidak ada yang membimbing aku?"' Lalu ia meminta Filipus naik dan duduk di sampingnya.

Dalam Injil Markus 1:17 Yesus berkata kepada mereka: "Mari, ikutlah Aku, dan kamu akan Kujadikan penjala manusia." Kata "Mari ikutlah Aku," menunjukkan bagaimana Tuhan Yesus mau membimbing murid-murid-Nya. Seakan-akan Tuhan Yesus berkata, "Aku melakukan dan engkau bersama-sama dengan Aku." 20 Tuhan Yesus tidak hanya memberi perintah tetapi Ia juga memberikan petunjuk dan arahan apa yang harus murid-murid-Nya lakukan dengan cara melihat apa yang Ia lakukan.

Menurut Warren, para pemimpin kaum muda memiliki dua fungsi: komunikator dan administrator. Sebagai administrator, ia mengarahkan orang yang dibimbingnya agar mereka dapat menikmati dan menghargai kebesaran Allah. ${ }^{21} \mathrm{Hal}$ ini menunjukkan bahwa tugas seorang pemimpin kaum muda adalah untuk membimbing orang-orang yang dipimpinnya agar dapat menerima berkat-berkat dari Allah dan pada akhirnya mereka akan memuliakan Allah. Seorang pemimpin kaum muda harus dapat membimbing orang-orang yang dipimpinnya agar dapat menikmati dan mengagumi karya Allah.

Jarot Wijanarko menuliskan dalam buku Father and Son bahwa mentor (dalam hal ini pemimpin kaum muda) adalah seorang yang lebih dewasa, yang secara nyata membimbing, baik dalam kehidupan seharihari maupun dalam hal rohani. ${ }^{22}$ Membimbing adalah merupakan tugas yang penting bagi pemimpin kaum muda agar dapat menghasilkan pemimpin yang lebih baik.

Dalam Alkitab menuliskan bahwa Paulus berhasil mementor Timotius menjadi seorang pemimpin jemaat dengan cara membimbingnya, seperti dikatakan dalam 2 Timotius 3:10, "Tetapi engkau telah mengikuti ajaranku, cara hidupku, pendirianku, imanku, kesabaranku, kasihku dan ketekunanku." Di sini Paulus tidak hanya memberikan pengetahuan tetapi memberikan hidupnya untuk dapat

${ }^{20}$ Dale Galloway \& $\mathbb{E}$ Warren Bird, On-Purpose Leadership: Multiplying Your Ministry by Becoming a Leader of Leaders (Jakarta: Harvest Publication House, 2003), 69.

${ }^{21}$ Warren S. Benson \& Mark H. Senter, Pedoman Lengkap Untuk Pelayanan Kaum Muda (Bandung: Yayasan Kalam Hidup, 1999), 78. 2016), 35

${ }^{22}$ Jarot Wijanarko, dkk., Father and Son (Jakarta: Keluarga Indonesia Bahagia, 
membimbing Timotius sehingga menjadi pelayan Tuhan muda yang efektif. Proses pembimbingan ini tidak dilakukan hanya di awal saja, tetapi sampai seorang pemimpin muda yang baru dapat dihasilkan bahkan proses ini terus berlanjut selama proses bimbingan tersebut dibutuhkan. Pemimpin kaum muda dikatakan dapat memahami tentang mentoring jika pemimpin tersebut melakukan tugasnya sebagai pembimbing bagi anggotanya.

\section{Melatih}

Setelah Tuhan Yesus memanggil murid-murid-Nya, Ia mengawali pelatihan dengan memberikan tujuan dari panggilan tersebut dan apa yang akan dilakukan oleh murid-murid-Nya dalam proses selanjutnya. Lukas 5:1-1l menceritakan bagaimana Yesus untuk pertama kalinya memanggil murid-murid-Nya. Kemudian Yesus mengajarkan kepada Simon untuk menjala ikan di tempat yang dalam dan hasilnya mereka mendapatkan ikan yang banyak, di sini Yesus mengajarkan kepada Simon tentang ketaatan dan mengandalkan Tuhan (ay. 5-6). Setelah itu, Yesus memberitahukan kepada mereka tentang tujuan panggilan dalam mengikuti-Nya yaitu untuk memenangkan jiwa dan memberikan mereka arahan bagaimana cara untuk memenangkan jiwa dengan memakai istilah menjadi "penjala manusia", sesuai dengan keadaan yang mudah di mengerti oleh mereka pada saat itu. Dalam Yohanes 21:6 Yesus mengingatkan kembali apa yang telah Ia latih kepada murid-murid-Nya tentang bagaimana mereka harus belajar percaya dan melakukan firman serta menjadi penjala manusia.

Dalam bukunya C. Gene Wilkes yang berjudul Jesus on Leadership, menuliskan bahwa hanya memberikan semangat kepada seseorang untuk ikut serta dalam pelayanan tidaklah cukup. Memberikan semangat tanpa pelatihan bagaikan semangat tanpa arah: Ada banyak bergerak ke sana ke mari tetapi hanya sedikit yang berhasil dikerjakan. ${ }^{23}$ Pelatihan merupakan tempat di mana pemimpin kaum muda memberikan pengetahuan dan keterampilan kepada anggotanya agar nantinya mereka memiliki pengetahuan dan keterampilan yang cukup untuk dapat menjadi pemimpin yang dapat melatih orang lain.

Kegiatan latihan merupakan elemen kepemimpinan sebagai pelayan yang paling penting dalam membantu orang untuk menyelesaikan sasaran kerja mereka. ${ }^{24}$ Khususnya bagi pelayanan pemuda di mana pemimpin kaum muda harus melatih generasi muda yang mungkin belum memiliki pengalaman dalam mengerjakan tugas-tugas atau tanggung jawab sebagai seorang pemimpin.

${ }^{23}$ Gene C. Wilkes, Jesus on Leadership (Jakarta: Bhuana Ilmu Populer, 2005), 221.

${ }^{24}$ Ken Blanchard and Phil Hodges, Lead Like Jesus (Jakarta: Visi Media, 2006), 162. 
Fungsi pemimpin kaum muda (mentor) sebagai pelatih adalah mengajar keterampilan-keterampilan (termasuk pengetahuan), memotivasi untuk mengobarkan karunia yang Tuhan berikan, menjadi model, dan mengevaluasi serta memberikan umpan balik kepada orangorang yang sedang dilatihnya. ${ }^{25}$

Ada tiga cara untuk menjadi pelatih kinerja: perencanaan kinerja, pelaksanaan pelatihan hari demi hari dan evaluasi kinerja. Perencanaan kinerja berurusan dengan menyediakan arah dan menetapkan sasaran. Pelaksanaan pelatihan hari demi hari menyangkut membantu orangorang untuk menang dalam menyelesaikan sasaran mereka, dengan mengamati kinerja mereka serta memuji kemajuan dan mengarahkan kembali usaha-usaha yang keluar dari rel (jalur yang telah ditetapkan). ${ }^{26}$ Pemimpin kaum muda dapat melihat kemajuan dari proses latihan yang telah dikerjakan oleh setiap anggota yang dilatih. Jika seorang pemimpin kaum muda tidak pernah melatih anggotanya, maka dapat dikatakan bahwa pemimpin tersebut tidak mengerti tentang peranan mentoring dalam kepemimpinnya.

\section{Mengutus}

Alkitab menuliskan bahwa dalam pelayanan Tuhan Yesus, Ia juga mengutus-murid-murid-Nya untuk memberitakan Injil. Dalam Markus 3:14-15 menuliskan, "Ia menetapkan dua belas orang untuk menyertai Dia dan untuk diutus-Nya memberitakan Injil dan diberi-Nya kuasa untuk mengusir setan." Bahkan sebelum Tuhan Yesus naik ke sorga, Ia tetap mengingatkan murid-murid-Nya untuk pergi memberitakan Injil. Dalam Injil Markus 16:15, "Lalu Ia berkata kepada mereka: Pergilah ke seluruh dunia, beritakanlah Injil kepada segala makhluk." Alkitab menuliskan setelah Tuhan Yesus mempersiapkan murid-murid-Nya, maka tahap selanjutnya adalah Ia mengutus mereka untuk pergi melakukan apa yang telah Ia ajarkan.

Pada dasarnya pengutusan ini bukan hanya sebuah perintah dari seorang pemimpin kepada anggotanya, tetapi pengutusan ini adalah bagian daripada proses mentoring. Dengan diberikannya tanggung jawab kepada anggota, maka mereka merasa bahwa dia dihargai dan dapat berarti bagi orang lain. Hal ini dapat menimbulkan rasa percaya diri bagi anggota tersebut sehingga pada saat ia menjadi seorang pemimpin, ia juga dapat memberi yang terbaik bagi anggotanya.

Pengutusan bukan semata-mata hanya menyerahkan tugas dan tanggung jawab, tetapi tentang pelaksanaan kepada yang menerima tanggung jawab tersebut. Pengutusan yang dilakukan oleh pemimpin

25 Amos Hosea, "Peranan Mentor dalam Pemberdaya Pelayanan," Majalah Generasi Edisi September-Desember, 2007, 9.

${ }^{26}$ Blanchard and Phil, 158. 
kaum muda (mentor), bertujuan supaya dapat terus bermultiplikasi atau berbuah, baik dalam hal kerohanian maupun dalam kepemimpinan. ${ }^{27}$ Tentunya sebelum mengutus anggotanya pemimpin kaum muda sudah mengetahui kemampuan setiap anggotanya, sesuai dengan talenta dan karunia yang Tuhan berikan.

Pengutusan dalam pelayanan, khususnya dalam pelayanan kaum muda berguna untuk mengefisiensikan setiap pekerjaan pelayanan yang di programkan. Selain itu pengutusan juga berguna untuk dapat memberdayakan anggota sesuai dengan kemampuan dan kapasitas masing-masing. Pengutusan juga berguna untuk melatih dan memberikan rasa percaya diri bagi setiap anggota, sehingga ke depannya mereka dapat menjadi pemimpin yang juga dapat mendelegasikan setiap pekerjaan pelayanan yang ada. Pengutusan juga berguna untuk mempercepat tercapainya rencana atau tujuan dalam suatu pelayan, bahkan dapat mempercepat proses multiplikasi pemimpin.

Setiap pemimpin yang baik perlu memahami serta menerapkan pengutusan (pendelegasian) dengan penuh tanggung jawab apabila ia menghendaki keberhasilan dalam kepemimpinannya. Pemimpin yang baik akan memahami bahwa ia hanya dapat bekerja dengan baik apabila ia dapat bekerja sama dan bekerja melalui orang lain (anggotanya). ${ }^{28}$ Pemimpin kaum muda yang tidak pernah mengutus anggotanya dalam tanggung jawab pelayanan, maka dapat dikatakan bahwa pemimpin kaum muda tersebut tidak memahami peranan mentoring dalam pelayanan.

\section{Multiplikasi}

Injil Markus 6:7, "Ia memanggil kedua belas murid itu dan mengutus mereka berdua-dua. Ia memberi mereka kuasa atas roh-roh jahat." Ayat ini menunjukkan bagaimana Tuhan Yesus memultiplikasikan pemimpin yang baru untuk dapat melayani jiwa-jiwa. Fungsi kepemimpinan bukan untuk menciptakan pengikut, tetapi untuk melahirkan pemimpin lainnya. Keberadaan pemimpin bukan untuk membuat generasi pengikut yang selalu berada dalam bayang-bayang pemimpinnya. ${ }^{29}$ Proses mentoring ada untuk melahirkan para pemimpin baru khususnya pemimpin kaum muda yang mungkin dapat lebih baik dari pemimpinnya.

Dalam Kisah Para Rasul 2:41-47 menuliskan cara hidup jemaat yang pertama. Setelah Yesus Kristus naik ke Sorga, maka murid-murid-Nya melakukan pelayanan dan proses mentoring. Hasilnya ditulis pada Kisah Para Rasul 2:47b, "Dan tiap-tiap hari Tuhan menambahkan jumlah mereka

\footnotetext{
27 Simanjuntak, 222.

${ }^{28}$ Semuel Tjiharjadi, dkk., To be A Great Effective Leader (Yogyakarta: ANDI, 2012), 290.

${ }^{29}$ Sendjaya, Kepemimpinan Kristen (Yogyakarta: Kairos Books, 2004), 229.
} 
dengan orang yang diselamatkan." Bahkan bukan hanya itu saja, lewat pelayanan murid-murid Yesus Kristus menghasilkan pengikut-pengikut baru yang akhirnya dapat melayani sampai ke luar dari bangsa Yahudi. Maka tergenapilah perintah Amanat Agung yang dikatakan oleh Yesus Kristus sebelum naik ke Sorga. Hal ini juga akan terjadi dalam pelayanan dalam gereja jika proses mentoring dapat berjalan dengan baik bagi generasi muda dalam gereja. Gereja akan bertumbuh dan bermultiplikasi, serta menghasilkan pemimpin-pemimpin rohani yang baru.

Tujuan akhir dari sebuah mentoring adalah reproduksi, berbuah, berlipat ganda atau bermultiplikasi. Di mana orang-orang yang dipimpin akan menjadi seorang yang memiliki kapasitas yang besar dan menjadi seorang pemimpin yang memberikan kontribusi yang berarti bagi Kerajaan Allah bahkan melebihi pemimpinnya sendiri. ${ }^{30}$ Pemimpin kaum muda yang memahami tentang proses mentoring akan mengalami multiplikasi pemimpin kaum muda yang baru.

\section{Dampak Bagi Perkembangan Pelayanan Pemuda di Gereja}

Tuhan Yesus datang ke dunia untuk melayani umat manusia, Dia tidak hanya melayani untuk kebutuhan rohani saja tetapi juga untuk kebutuhan jiwa (keselamatan jiwa/jiwa yang dibarui), dan kebutuhan jasmani (memberikan kesembuhan). Dalam Matius 9:35 menuliskan, "Demikianlah Yesus berkeliling ke semua kota dan desa; Ia mengajar dalam rumah-rumah ibadat dan memberitakan Injil Kerajaan Sorga serta melenyapkan segala penyakit dan kelemahan."

Hutchcraft dan Whitmer menjelaskan dalam bukunya berjudul Perjuangan untuk Sebuah Generasi bahwa cara terbaik untuk melayani generasi muda diawali dengan memenuhi kebutuhan mereka. ${ }^{31} \mathrm{Hal}$ ini menunjukkan bahwa pelayanan kaum muda juga harus berusaha untuk memenuhi kebutuhan anggotanya sesuai dengan perkembangan zaman. Dalam hal ini gereja juga harus memerhatikan kebutuhan tubuh, jiwa dan roh dari generasi muda dengan seimbang. Jika kebutuhan tersebut tidak dipenuhi dengan baik dan seimbang bagi generasi muda, maka mereka dapat mengalami pertumbuhan yang tidak seimbang. Dan hal ini dapat merugikan generasi muda itu sendiri, gereja dan lingkungan di mana mereka berada.

Lewat pemahaman pemimpin kaum muda tentang mentoring akan mengakibatkan lahirnya pemimpin-pemimpin yang baru. Dampak dari lahirnya pemimpin-pemimpin baru yang berkualitas adalah terjadinya perkembangan dalam pelayanan. Kita melihat bagaimana Yosua yang

\footnotetext{
30 Simanjuntak, 79.

${ }^{31}$ Ron Hutchcraft dan Lisa Hutchcraft, Perjuangan untuk Sebuah Generasi (Jakarta: Metanoia, 2004), 41.
} 
mampu menaklukkan tanah Kanaan, Elisa yang memiliki pengurapan dua kali ganda, Timotius yang dapat membangun jemaat yang besar serta Yesus Kristus yang berhasil mementor para rasul-rasul. Dengan lahirnya dan berkembangnya pemimpin yang baru maka diharapkan pelayanan akan mengalami perkembangan.

Mentor bermanfaat sebagai bentuk sifat relasional formasi pelayanan ketika mereka mendengar pemuda berbagi tentang kasih mereka yang mendalam kepada Tuhan dan mereka berkomitmen untuk melayani gereja, dan dunia secara keseluruhan. Sebagian besar pemuda dengan tulus mencari pemahaman yang lebih jelas tentang panggilan, dan panggilan pelayanan mereka. ${ }^{32}$

Pemuda dapat berpartisipasi dalam apa yang Tuhan lakukan di dunia. Sifat relasional mentoring yang terfokus pada pembentukan pelayanan dapat membantu seminari-seminari teologis atau gereja menjadi sadar akan beragam isu, dan tantangan yang dihadapi pemuda ketika mereka mempersiapkan kehidupan pelayanan. Tuhan masih memanggil pemuda untuk melayani di gereja, dan mereka mencari orang dewasa yang signifikan untuk membimbing, dan membimbing mereka melalui proses mentoring ini. ${ }^{33}$ Dengan adanya pemimpin kaum muda yang paham tentang mentoring, dan dengan bertambahnya pemimpin kaum muda baru (hasil mentoring) yang juga paham tentang mentoring, maka akan terjadi perkembangan pelayanan pemuda di gereja dan perkembangan pelayanan akan terus-menerus mengalami pertumbuhan.

\section{Kesimpulan}

Peran Pemimpin kaum muda dalam menjalankan proses mentoring dapat menghasilkan pemimpin baru yang transformatif. Proses mentoring yang harus dilakukan oleh pemimpin adalah memberikan contoh teladan yang alkitabiah, membimbing, melatih, dan mengutus sehingga hasil mentoring berdampak multiplikasi pemimpin-pemimpin kaum muda yang baru, dan memiliki kemampuan untuk mengembangkan pelayanan pemuda di gereja. Setiap perkembangan pelayanan yang dihasilkan oleh setiap pemimpin kaum muda tentunya untuk memuliakan nama Tuhan Yesus Kristus, dan untuk menggenapi Amanat Agung Tuhan Yesus Kristus.

\footnotetext{
32 Nathan Chiroma, "Mentoring and the ministerial formation of seminary students," Stellenbosch Theological Journal 3, no. 1 (2017): 63, http://dx.doi.org/10.17570/stj.2017.v3nl.a0363

33 Nathan Chiroma, "Mentoring and the ministerial formation of seminary students," Stellenbosch Theological Journal 3, no. 1 (2017): 63, http://dx.doi.org/10.17570/stj.2017.v3nl.a0363.
} 


\section{Kepustakaan}

Barna Group. "Year in review: Barna's top 10 findings in 2015. Culture \& Media." Retrieved from https://barna.org/research/culturemedia/article/year-in-review-2015.

Benson, Warren S., Mark H. Senter. Pedoman Lengkap Untuk Pelayanan Kaum Muda. Bandung: Yayasan Kalam Hidup, 1999.

Blanchard, K., Phil Hodges, Lead Like Jesus. Jakarta: Visi Media, 2006. Planning Programs for Adult Learners: A Practical Guide for Educators, Trainers and Staff Developers. San Fransisco: Jossey-Bass Publishers, 1994.

Chandra, Robby. Landasan Pacu Kepemimpinan. Yogyakarta: Gloria Graffa, 2004.

Chiroma, Nathan. "Mentoring and the ministerial formation of seminary students." Stellenbosch Theological Journal 3, no. 1 (2017): 51-68.

Chiroma, N. H., A. Cloete. "Mentoring as a supportive pedagogy in theological training." HTS Teologiese Studies/ Theological Studies 71, no. 3 (2015): 1-8. http:// dx.doi.org/10.4102/hts. v7li3.2695.

"COO CBN Indonesia: Kita Sedang Kehilangan Satu Generasi." Diakses 20 Mei 2018.

https://www.jawaban.com/read/article/id/2015/06/09/90/15060917 0913/COO-CBN-Indonesia\%3A-Kita-Sedang-Kehilangan-SatuGenerasi.

Elmore, Tim. Mentoring. Jakarta: Metanoia, 2003.

"Fakta Yang Menyebabkan Anak Muda Meninggalkan Gereja. Apakah Gereja Mau Berdiam Diri Saja?" Diakses 5 Mei 2018. http://www.superbookindonesia.com/article/read/584.

Galloway, Dale \& W Warren Bird. On-Purpose Leadership: Multiplying Your Ministry by Becoming a Leader of Leaders. Jakarta: Harvest Publication House, 2003.

Horan, Anne Puidk. "Fostering Spiritual Formation of Millennials in Christian Schools." Journal of Research on Christian Education 26, no. 1 (2017): 56-77. http://dx.doi.org/10.1080/10656219.2017.1282901.

Hosea, Amos. "Peranan Mentor dalam Pemberdayaan Pelayan." Majalah Generasi DPA GBI Edisi September-Desember 2007.

Hutchcraft, R., Lisa Hutchcraft. Perjuangan untuk Sebuah Generasi. Jakarta: Metanoia, 2004.

Joo, Min-Kyu, Gyu-Chang Yu, Leanne Atwater. "Formal leadership mentoring and motivation to lead in South Korea." Journal of Vocational Behavior 107 (August 2018): 310-326.

Kinnaman, David. You Lost Me: Why Young Christians Are Leaving Church... and Rethinking Faith. Grand Rapid, MI: Baker Books, 2011. 
Leo, Eddy. Mentoring Panduan Untuk Menuntun Hidup Orang Lain Menjadi Maksimal Dalam 49 Hari. Jakarta: Metanoia, 2007.

Sendjaya. Konsep Karakter Kompetensi Kepemimpinan Kristen. Yogyakarta: Kairos Books, 2004.

Simanjuntak, Togi. The Art of Mentoring. Jakarta: Metanoia, 2012.

Sumule, Leonard. "The Impact of Informal Mentoring: Perceptions of Alumni of Evangelical Theological Schools in Indonesia." ProQuest LLC (2016).

Tjiharjadi, Semuel dkk. To be A Great Effective Leader. Yogyakarta: ANDI, 2012.

Wahyudi, Josua Iwan. Pharaoh Leadership. Jakarta: Get Yor Wisdom Publishing, 2013.

Wijanarko, Jarot dkk. Father and Son. Jakarta: Keluarga Indonesia Bahagia, 2016.

Wilkes, Gene C. Jesus on Leadership. Jakarta: Bhuana Ilmu Populer, 2005. 